DIW BERLIN

Discussion

Papers
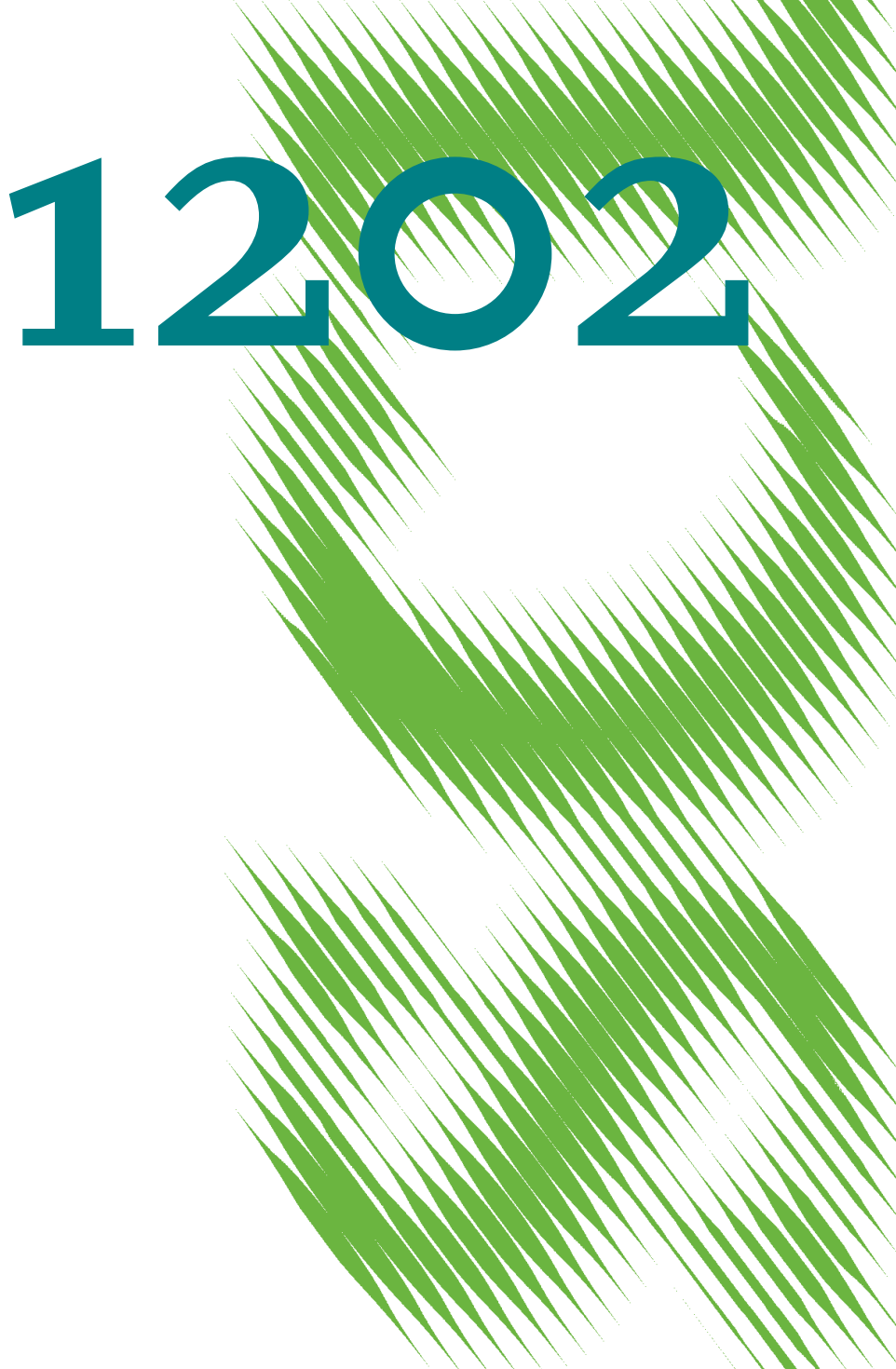

Absorptive Capacities and the Impact of FDI on Economic Growth 
Opinions expressed in this paper are those of the author(s) and do not necessarily reflect views of the institute.

IMPRESSUM

(C) DIW Berlin, 2012

DIW Berlin

German Institute for Economic Research

Mohrenstr. 58

10117 Berlin

Tel. $+49(30) 89789-0$

Fax +49 (30) $89789-200$

http://www.diw.de

ISSN print edition $1433-0210$

ISSN electronic edition 1619-4535

Papers can be downloaded free of charge from the DIW Berlin website:

http://www.diw.de/discussionpapers

Discussion Papers of DIW Berlin are indexed in RePEc and SSRN:

http://ideas.repec.org/s/diw/diwwpp.html

http://www.ssrn.com/link/DIW-Berlin-German-Inst-Econ-Res.html 


\title{
Absorptive Capacities and the Impact of FDI on Economic Growth*
}

\author{
Beatrice Farkas \\ DIW Berlin
}

March, 2012

\begin{abstract}
This paper analyzes the necessary local conditions required for the existence of positive spillovers from multinationals' entry and it consists of a unified study of absorptive capacities. We start from the idea that FDI speeds up the diffusion of technologies across countries. Yet, the question that arises is: to what extent are these advanced technologies absorbed and successfully internalized by the receiving countries such that they materialize in welfare gains? The impact of FDI depends on the country specific absorptive capacity. We first interact FDI individually with different growth determinants and we find that the contribution of FDI to economic growth is positive and significant depending on the level of human capital and the development of financial markets, but its presence in developing countries must complement rather than substitute a set of other growth determinants. Then we test the robustness of the linear interaction terms relative to each other and we analyze the set of conditions that are most beneficial for FDI.
\end{abstract}

Keywords: FDI, Economic Growth, Absorptive Capacity

JEL Classification: F23, F26, F43

*Contact: bfarkas@diw.de. 


\section{Introduction}

Since the 1990s, the world has experienced an unprecedented upsurge of FDI flows. World FDI more than tripled since 1990 and, as of 2000, more than 50\% of the private capital flows of developing countries come via foreign investments. These stylized facts suggest that FDI is now very much a global affair and its increasing importance as a catalyst that boosts the growth of developing countries is just another feature of globalization.

However, experience has shown that some countries experienced higher growth rates as a result of increased FDI, while others did not. Previous studies analyze the required conditions for FDI to have a positive impact on growth. One of the proposed explanations in the literature consists of the idea that positive spillovers from FDI depend on the absorptive capacity of a country, i.e., on the existence of various local conditions favorable to economic growth. This explanation is based on the concept that FDI is a channel through which developing countries gain access to advanced technologies and increase their TFP. But in order to absorb these advanced technologies, host economies need to meet certain conditions that define the absorptive capacity of a country.

This paper analyzes the optimal mix of such conditions that allows FDI to speed up growth. We evaluate different combinations of measures for absorptive capacity that could generate the most favorable economic environment for positive spillovers from FDI. Therefore, we carry out a unified study of absorptive capacities by analyzing the simultaneous interactions of FDI with other growth determinants and their effect on economic growth. The set of these growth determinants consists of various measures for absorptive capacity that were individually and separately taken into account by the previous literature (development of financial markets, level of human capital, trade openness, natural resource abundance). 
The contribution of this paper lies in our empirical approach. We construct linear interaction terms between FDI and each proxy for absorptive capacity and then we evaluate the robustness of these interaction terms relative to each other. Thus we analyze all possible combinations of favorable conditions that are the most beneficial for FDI and their outcome on the impact of FDI on growth. We find that countries with well developed financial markets that have either low agricultural exports or low oil exports constitute the optimum setting for welfare gains from FDI to exist. Our results indicate that positive spillovers from FDI may coexist with low human capital only if the financial markets of the host country are well developed. Also, the results suggest that oil abundant countries that trade intensively have lower growth rates as a result of FDI.

As an exercise, we then employ the empirical approach of the previous literature by regressing FDI and individual interaction terms on growth rates. We find that gains from FDI exist only when FDI interacts with well developed financial markets and relatively high levels of human capital that induce growth. We then analyze the extent to which these requirements differ across various regions of the world. Previous studies show that although the first and immediate benefit from FDI comes from the direct capital financing carried out by foreign investors, there is a further contribution by FDI to growth, which consists mainly of technology diffusion from rich to poor countries. As Romer (1990) first pointed out, cross-country differences in GDP per worker are accounted for by the huge gaps of ideas across counties (i.e., gaps between technologies and productivities with which rival inputs are used or TFP). Since multinational corporations (MNC) have undertaken a major part of world's R\&D, their presence in developing countries facilitates technology transfer. This process can take the form of imitation/adoption of technologies, formation of forward and backward linkages between industries, and a higher productivity of using the existing technologies. The common intuition is that FDI should have only positive effects on the development of host economies by giving rise to technology diffusion, productivity 
gains, access to emerging markets, transfer of business know-how, and employee training. As a consequence, developing countries have eased the restrictions on FDI by offering tax incentives and subsidies in order to attract foreign capital. However, empirical evidence shows that thedirection of causality between FDI and growth is ambiguous in the sense that it is still not clear whether FDI determines growth or vice versa. More often than not, studies based on micro level data do not find significant positive effects of FDI on growth, whereas the consensus among macroeconomic studies (that use FDI flows for cross sections of countries) is that FDI may speed up growth conditional on the absorptive capacity of the host country. In other words, these studies suggest that the extent to which foreign technologies are internalized by developing countries is dependent on the absorptive capacity. The rest of the paper is organized as follows: the next subsection presents the findings of the previous literature; Section 2 presents the empirical methodology and the results. Section 3 concludes.

\subsection{Related Literature}

A recurring idea in the previous literature is the condition for a developing country to have reached a certain threshold of development for positive spillovers from FDI to exist. The magnitude of spillovers or, in other words, the impact of FDI on economic growth varies with the absorptive capacity of the host economy. Previous studies show that the absorptive capacity depends on a minimum threshold level of human capital, well developed financial markets, trade openness, levels of income, and technological gap. Borensztein, De Gregorio and Lee (1998) show that is takes an educated labor force to spread the benefits of new technologies across all industries. Foreign investments are able to speed up growth only when there is a minimum threshold level of human capital in the host economy. Their findings indicate that the gains from FDI come through technology diffusion rather than through capital accumulation. Alfaro, Chanda, Kalemli-Ozcan, and Sayek (2004) point 
out that economies with well developed financial markets gain significantly from FDI. The level of development of the financial market is a deciding factor whether MNC's operate isolated in enclaves or they become catalysts for technology transfers. Blomstrom, Lipsey, and Zejan (1994) show that FDI has a significant impact on growth and positive spillovers from FDI depend on the income level of the host economy, but not on education. According to Balusubramayam, Salisu, and Sapsford (1999), trade openness is another component of a country's absorptive capacity that increases the contribution of FDI to economic growth. Carkovic and Levine (2002) show that the benefits from FDI are conditional on other growth determinants, while the exogenous component of FDI does not have a robust positive effect on growth. Therefore they show that FDI, per se, does not have a direct influence on growth. A vast part of the literature addresses the issue of the relationship between FDI spillovers and absorptive capacities. According to the first strand of the literature, this relationship is positive and linear. The idea dates back to the "relative backwardness" hypothesis of Findlay (1978), which states that the rate of technological progress of a relatively backward country is an increasing function of the technological gap. Therefore the absorptive capacity is measured as the size of the technological gap and technology diffusion from FDI takes place through a "contagion effect". As a result, FDI increases the rate of technological progress in the host country. The other view considers a quadratic relationship between FDI and absorptive capacity. Girma (2005) uses firm level data from UK and finds that the effect of FDI on TFP growth depends on the absorptive capacity that is defined as the distance of a firm from the technological leader in the industry. He shows that there is a non-linear relationship between absorptive capacities and spillovers from FDI. In Girma and Gorg (2005), FDI is interacted with absorptive capacity. They show that there is a U-shaped relationship between this interaction term and TFP growth suggesting that improvements in absorptive capacity at the firm level allow the firm to enhance the spillovers from FDI. 


\section{Empirical Analysis}

\section{$2.1 \quad$ Data}

Our dataset consists of a cross-section of 69 countries and comprises measures for FDI and for other determinants of economic growth between 1975 and 2000. Several sources were used to construct the data. We begin with a short description of the measures used in our analysis. Data for growth rates, real GDP per capita, investment rates, and trade are extracted from Penn World Tables 6.1. The average of annual growth rates of real GDP per capita represents the dependent variable in our regression analysis. The initial GDP enters as the $\log$ of real PPP GDP per capita, while the investment rate is measured as the log of average of investment shares in real GDP per capita. Openness to trade is calculated as the log of total trade as a percentage of current GDP i.e., $\log \left(\frac{X+M}{P P P G D P}\right)$, where $X$ and $M$ denotes exports and imports in real prices. Data for FDI are obtained from World Development Indicators. FDI represents the sum of equity capital, reinvestments and other types of capital and it is measured as average of net inflows of foreign investment as percentage of GDP. As a financial market indicator we use the log of private credit (credit by deposit money banks to GDP) provided by Easterly (2001). Data for educational attainment is provided by Barro and Lee (2001), which reports the average years of secondary schooling in total population over the age of 25. Data for other explanatory variables, such as agriculture and oil exports are obtained from World Development Indicators. We use the log of average of agricultural raw materials exports in total merchandise exports and the log of average fuel exports in total merchandise exports in current US\$ as controls for natural resources abundance. Finally, we add fixed factors in our analysis in order to control for region and income levels. The data ${ }^{1}$ are provided by Easterly (2001).

\footnotetext{
${ }^{1}$ http://www.nyu.edu/fas/institute/dri/globaldevelopmentnetworkgrowthdatabase.html
} 


\subsection{Methodology}

The purpose of our empirical exercise is estimate the impact of FDI on growth and to examine the channels through which FDI can bring welfare gains to the recipient country.

Table 1 presents the summary statistics of the data. The data reflects a high cross country variation in the shares of FDI in GDP; FDI inflows in Singapore are 47 times that of South Africa, while on average, FDI represents 1.76 percent of GDP. The highest growth rate over the 1975-2000 period was attained by South Korea (6.081), while Nicaragua experienced the lowest negative growth rate (-3.052). China's spectacular development is reflected in its growth rate $(5.835 \%$-the second highest in the sample), while its initial GDP takes the second to last position in the ranking. Regarding human capital, the educational attainment level in Malawi represent 3\% of the U.S. level. Table 2 presents the correlation matrix for the data averaged over the 1975-2000 period.

We estimate the effects of FDI on economic growth after controlling for other growth determinants. Thus the regression equation for the cross section data of 69 countries is given by:

$$
G R O W T H_{i}=\beta_{0}+\beta_{1} \log G D P_{1975_{i}}+\beta_{2} C O N T R O L S_{i}+\beta_{3} F D I_{i}+\epsilon_{i}
$$

The set of control variables consists of investment rate, human capital, financial development indicator, openness to trade, agricultural exports, and natural resource abundance (oil exports) of the host country.

Previous studies explore the channels through which FDI may speed up growth by analyzing the interaction between FDI and other determinants of economic growth. Thus, we first linearly interact FDI with five different measures for absorptive capacity. We estimate five additional regression equations corresponding to the interaction terms that are added as explanatory variables: FDI x Financial markets, FDI x Trade, FDI x Schooling, FDI x Oil, and FDI x Agriculture. The interaction terms are the regressors used for testing the 
Table 1: Summary Statistics. Based on a sample of 69 countries using the average over the 1975-2000 period. Variables GDP 1975 , I rate, PC, Trade, Oil, and Agriculture are included in regressions as logarithms.

\begin{tabular}{|l|rrrr|}
\hline Variable & Mean & Std. Dev. & Min & Max \\
\hline \hline Growth & 1.890 & 1.683 & -3.052 & 6.081 \\
GDP ${ }_{1975}$ & 8.532 & 0.885 & 6.435 & 9.922 \\
School & 1.827 & 1.042 & 0.167 & 4.576 \\
I rate & 2.795 & 0.411 & 1.907 & 3.789 \\
Private credit & -1.150 & 0.703 & -3.314 & 0.311 \\
Trade & 3.506 & 0.735 & 1.536 & 5.646 \\
Oil & -0.867 & 2.059 & -8.726 & 3.050 \\
Agriculture & 1.123 & 1.373 & -3.428 & 3.548 \\
FDI & 1.764 & 1.637 & 0.042 & 10.107 \\
\hline
\end{tabular}

significance of those local conditions that ease the absorption of foreign technologies and thus, complement FDI in creating welfare gains in the receiving country. Both FDI and the measure for absorptive capacity are included as well in the new regressions, to avoid the omitted variables problem. Thus, the regressions that estimate the effect of absorptive capacity (ABSCAP) on FDI spillovers and implicitly, on growth are given by:

$$
G R O W T H_{i}=\beta_{0}+\beta_{1} F D I_{i}+\beta_{2}\left(F D I_{i} * A B S C A P_{i}\right)+\beta_{3} A B S C A P_{i}+\beta_{4} C O N T R O L S+\epsilon_{i}
$$

We then account for continent and level of development by adding fixed factors for region and income levels to the regressions. In this sense, dummy variables for Sub-Saharan and Latin American countries are added to control for region, while dummy variables for 
Table 2: Correlation matrix. Based on a sample of 69 countries using the average over the 1975-2000 period. Variables GDP 1975 , I rate, PC, Trade, Oil, and Agriculture are included in regressions as logarithms.

\begin{tabular}{|l|rcccccccc|}
\hline Variable & Growth & GDP 1975 & School & I rate & PC & Trade & Oil & Agric & FDI \\
\hline \hline Growth & 1.00 & & & & & & & & \\
GDP ${ }_{1975}$ & -0.02 & 1.00 & & & & & & & \\
School & 0.26 & 0.75 & 1.00 & & & & & & \\
I rate & 0.46 & 0.63 & 0.63 & 1.00 & & & & & \\
PC & 0.41 & 0.54 & 0.58 & 0.68 & 1.00 & & & & \\
Trade & 0.16 & 0.56 & 0.51 & 0.49 & 0.49 & 1.00 & & & \\
Oil & 0.06 & 0.23 & 0.19 & 0.17 & 0.11 & 0.26 & 1.00 & & \\
Agric & -0.09 & -0.18 & -0.11 & -0.18 & -0.17 & -0.18 & -0.16 & 1.00 & \\
FDI & 0.24 & 0.25 & 0.17 & 0.29 & 0.26 & 0.58 & 0.32 & -0.06 & 1.00 \\
\hline
\end{tabular}

developing and high income OECD countries are used to control for levels of development.

Finally, we carry out a unified study of absorptive capacities to evaluate the mix of necessary conditions that are required for FDI to increase the growth rate. We test the robustness of the five measures for absorptive capacity relative to each other. Thus we estimate ten regression equations that contain two interaction terms at a time:

$$
\begin{aligned}
G R O W T H_{i} & =\beta_{0}+\beta_{1} F D I_{i}+\beta_{2}\left(F D I_{i} * A B S C A P 1_{i}\right)+\beta_{3}\left(F D I_{i} * A B S C A P 2_{i}\right) \\
& +\beta_{4} A B S C A P 1_{i}+\beta_{5} A B S C A P 2_{i}+\beta_{6} C O N T R O L S+\epsilon_{i}
\end{aligned}
$$

The purpose of this exercise is to analyze the combinations of factors that would generate the highest payoffs from FDI for a receiving country. The previous literature shows that a 
threshold level of human capital or well developed financial markets are essential for FDI to bring beneficial effects on the host economy. Yet, in this study, we are interested in finding out how a simultaneous interaction of this factors with FDI might change the impact of foreign investments on growth.

\subsection{Results}

The results confirm without exception the significant impact of initial levels of income, human capital and investment rates on economic growth. The coefficients of these regressors are all positive and strongly significant at 5\% level. FDI has a positive and significant effect on growth rate of GDP per capita even when absorptive capacities are not taken into consideration. Our estimates of the regression equation (1) are presented in column (1) of Table 3. The results indicate that the regression coefficient for FDI (0.224) is significant at $10 \%$ level, suggesting that a $1 \%$ increase in the share of FDI in GDP is associated with 0.224 $\%$ increase in the growth rate of GDP per capita. The coefficient for financial development indicator (private credit) is positive and statistically significant at $10 \%$ level, such that a $1 \%$ increase in private credit increases the growth rate by $0.05 \%$.

The estimation results of equation (2) are reported in columns (2), (3), (4), and (5) of Table 3. The estimates highlight the positive effect of FDI on the growth rates of recipient countries when absorptive capacities are taken into consideration. After adding the interaction term between FDI and financial development indicator, the contribution of FDI to growth more than doubles at 5\% significance level. The interaction term FDI x Fin enters positively (0.334) and it is statistically significant at $5 \%$ level, confirming that well developed financial markets are vital for FDI to enhance growth. When FDI x Agric is added in the regression, the coefficient for FDI increases (0.305) and remains significant at 5\%, but the coefficient of the interaction term, although not significant, is negative, suggesting that FDI 
is growth enhancing in economies where the share of agricultural exports in GDP is low. Although not significant, the coefficients for FDI remain positive when FDI is interacted with oil exports and human capital, while the interaction with trade brings a negative (but insignificant) impact of FDI on the convergence rate of the host country.

Fixed factors that control for region and level of income are added in regression equation (2) along with linear interaction terms. The results are presented in Tables 4 and 5 . The coefficient estimates of dummy variables for developing and high income OECD countries are negative and insignificant. However, after adding dummy variables for income levels in regressions, the coefficient for FDI becomes significant not only when FDI is interacted with private credit and agriculture, but also when the the absorptive capacity is proxied by human capital endowment and trade openness. Moreover, after we regress FDI x School on growth rate, both the coefficient of FDI (0.044) and the coefficient on the interaction term (0.071) are significant at $5 \%$ level and positive. These results confirm the findings of the previous literature that FDI induces growth in countries that have sufficiently high endowments of human capital.

We then add continental dummies for Sub-Saharan and Latin American countries in the regression equation (2). The regression results are presented in Table 5. The coefficients for both dummy variables suggest that location brings a penalty to the growth rates of African and Latin American countries. We then add continental dummies for Sub-Saharan and Latin American countries in the regression equation (2). The regression results are presented in Table 5. The coefficients for both dummy variables suggest that location brings a penalty to the growth rates of African and Latin American countries. The growth rates of Latin American countries are $0.96 \%$ lower than of the rest of the world when FDI is interacted with financial development. Adding the interaction term between FDI and Agriculture brings down the growth rates of Latin American countries even lower (they are $1.11 \%$ lower than the growth rates of the rest of the sample). In both of these cases, the coefficients for Latin 
America dummies are significant at 5\% level. Since agriculture accounts for an important fraction of GDP in Sub-Saharan countries, we analyze the way in which the volume of agricultural exports affects the relationship between FDI and growth in African countries. Column (2) in Table 5 shows that the interaction term FDI x Agriculture enters negatively, while the coefficient for FDI (0.362) is positive and significant at 5\% level. This result suggests that the lower the agricultural intensity in Sub-Saharan countries, the higher the contribution of FDI to growth. In this case, the dummy coefficient for Sub-Saharan countries (-0.901) indicates that their growth rates are $90 \%$ lower than of the reference group.

Our results suggests that natural resource abundance does not influence significantly FDI's effect on growth. When absorptive capacity is proxied by the volume of oil exports, the coefficients of both FDI and interaction term become insignificant whether we add continental and income dummy variables or not.

Finally, we test the robustness of these five measures of absorptive capacity relative to each other. We construct pairs of absorptive capacities and we regress their simultaneous interaction with FDI on the growth rate of GDP per capita. The regression equation is given by (3). Table 6 reports the estimated coefficients for FDI and for the pair of interaction terms considered in each regression. The first column presents the regression coefficients for FDI and interaction terms when FDI $x$ Fin is regressed successively with FDI x Schooling, FDI $\mathrm{x}$ Oil, FDI x Agriculture, and FDI x Trade, respectively. In the second column, FDI $\mathrm{x}$ Schooling is regressed together with FDI x Oil, FDI x Agriculture and FDI x Trade- one at a time. The third column reports the interaction of FDI x Oil with FDI x Agric and FDI x Trade. 
Table 3: FDI and per capita GDP growth: effects of different measures of absorptive capacity on growth The dependent variables are the average of per capita GDP growth rates from 1975 to 2000. Control variables: GDP $1975=$ initial GDP per capita; Schooling=educational attainment; I rate=investment rate, PC=private credit as \% in GDP; Trade=total trade as \% of GDP; Oil=oil exports as \% of GDP; Agriculture=agricultural exports as \% in GDP; FDI=share of FDI in GDP. Variables GDP1975, I rate, PC, Trade, Oil, and Agriculture are included in regressions as $\log ($ variable). P-values are in parentheses below coefficient estimates.

\begin{tabular}{|c|c|c|c|c|c|c|}
\hline Independent variable & (1) & FDI $x \underset{(2)}{\operatorname{Fin}}(\mathrm{PC})$ & $\begin{array}{c}\text { FDI x Agriculture } \\
(3)\end{array}$ & $\begin{array}{c}\text { FDI x Oil } \\
\text { (4) }\end{array}$ & $\begin{array}{c}\text { FDI x Schooling } \\
(5)\end{array}$ & $\begin{array}{c}\text { FDI } x \text { Trade } \\
(6)\end{array}$ \\
\hline$\overline{G D P}$ & -1.420 & $-1.296^{* * *}$ & $-1.440^{* * *}$ & $-1.403^{* * *}$ & $-1.423^{* * *}$ & $-1.391^{* * *}$ \\
\hline & $(0.000)$ & $(0.000)$ & $(0.000)$ & $(0.000)$ & $(0.000)$ & $(0.000)$ \\
\hline \multirow[t]{2}{*}{ Schooling } & $0.606^{* *}$ & $0.642^{* *}$ & $0.542^{* *}$ & $0.612^{* *}$ & 0.524 & $0.629^{* *}$ \\
\hline & $(0.019)$ & $(0.013)$ & $(0.038)$ & $(0.018)$ & $(0.181)$ & $(0.016)$ \\
\hline \multirow[t]{2}{*}{ I rate } & $2.123^{* * *}$ & $1.820^{* * *}$ & $2.400^{* * *}$ & $2.052^{* * *}$ & $2.158^{* * *}$ & $1.976^{* * *}$ \\
\hline & $(0.001)$ & $(0.005)$ & $(0.000)$ & $(0.001)$ & $(0.001)$ & $(0.002)$ \\
\hline \multirow[t]{2}{*}{$\mathrm{PC}$} & $0.540^{*}$ & 0.158 & $0.559^{*}$ & $0.552^{*}$ & $0.547^{*}$ & $0.571^{*}$ \\
\hline & $(0.100)$ & $(0.704)$ & $(0.088)$ & $(0.095)$ & $(0.099)$ & $(0.086)$ \\
\hline \multirow[t]{2}{*}{ Trade } & -0.265 & -0.358 & -0.235 & -0.247 & -0.273 & -0.399 \\
\hline & $(0.412)$ & $(0.274)$ & $(0.465)$ & $(0.449)$ & $(0.403)$ & $(0.278)$ \\
\hline \multirow[t]{2}{*}{ Oil } & 0.001 & -0.014 & 0.005 & -0.053 & -0.000 & -0.000 \\
\hline & $(0.987)$ & $(0.859)$ & $(0.950)$ & $(0.670)$ & $(0.997)$ & $(0.995)$ \\
\hline \multirow[t]{2}{*}{ Agriculture } & -0.067 & -0.118 & 0.122 & -0.069 & -0.066 & -0.076 \\
\hline & $(0.575)$ & $(0.340)$ & $(0.546)$ & $(0.563)$ & $(0.584)$ & $(0.527)$ \\
\hline \multirow[t]{2}{*}{ FDI } & $0.224^{*}$ & $0.468^{* *}$ & $0.305^{* *}$ & 0.179 & 0.110 & -0.196 \\
\hline & $(0.077)$ & $(0.029)$ & $(0.036)$ & $(0.227)$ & $(0.796)$ & $(0.722)$ \\
\hline \multirow[t]{2}{*}{ FDI x absorptive capacity } & & $0.334^{* *}$ & -0.098 & 0.031 & 0.055 & 0.088 \\
\hline & & $(0.045)$ & $(0.249)$ & $(0.557)$ & $(0.782)$ & $(0.436)$ \\
\hline$R^{2}$-adjusted & 0.409 & 0.420 & 0.413 & 0.403 & 0.400 & 0.406 \\
\hline Observations & 69 & 69 & 69 & 69 & 69 & 69 \\
\hline
\end{tabular}

$a[]^{* * *}$ represents significant at $1 \%$ level; ${ }^{* *}$ represents significant at $5 \%$ level; ${ }^{*}$ represents significant at $10 \%$ level 
Table 4: FDI and per capita GDP growth: effects of different measures of absorptive capacity on growth. Fixed factor added: dummy for high income OECD countries The dependent variables are the average of per capita GDP growth rates from 1975 to 2000; P-values are in parentheses below coefficient estimates.

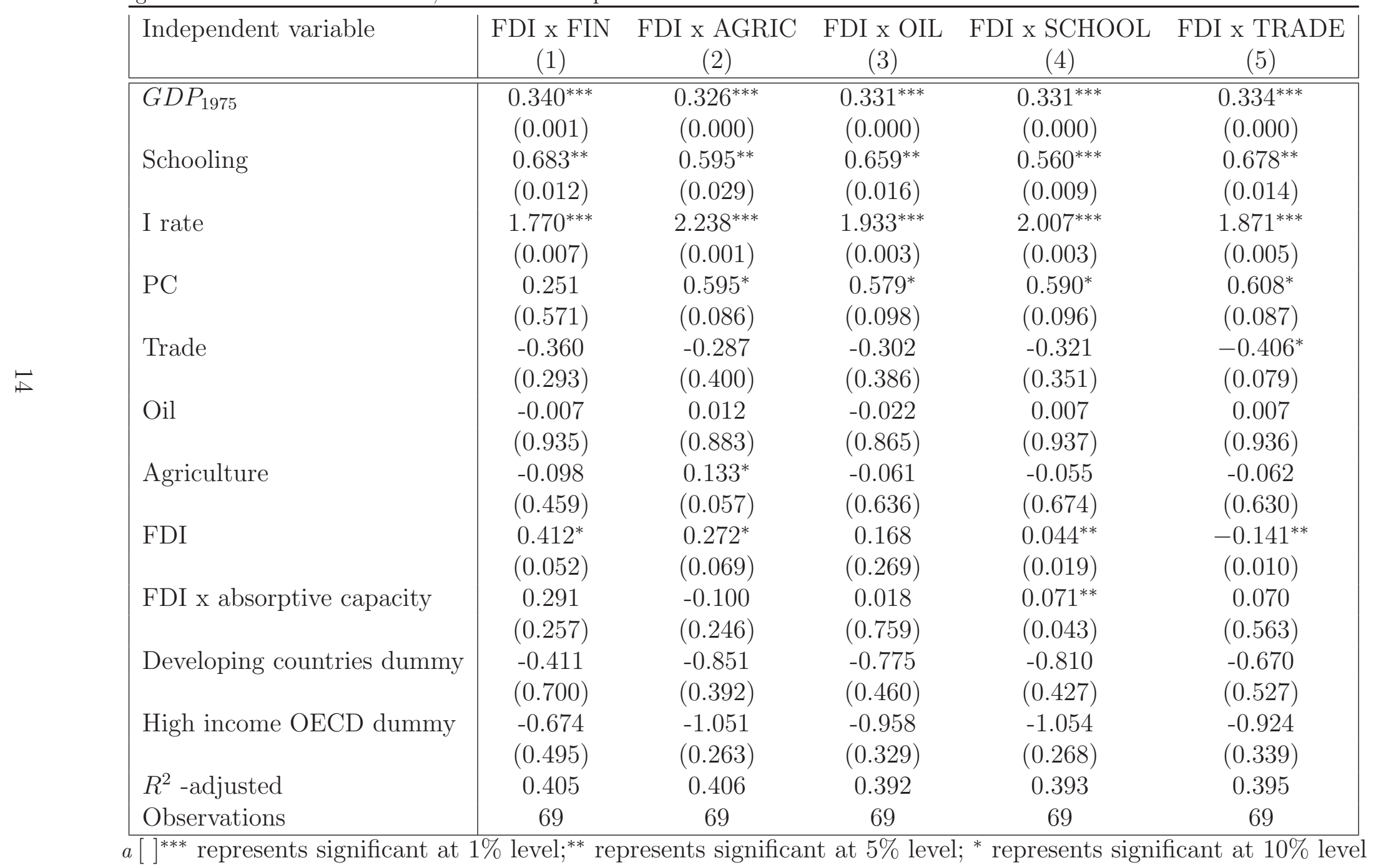


Table 5: FDI and per capita GDP growth: effects of different measures of absorptive capacity on growth. Fixed factors added: dummies for Sub-Saharan and Latin American countries The dependent variables are the average of per capita GDP growth rates from 1975 to 2000. Control variables: GDP1975=initial GDP per capita; Schooling=educational attainment; I rate=investment rate, $\mathrm{PC}=$ private credit as \% in GDP; Trade=total trade as \% of GDP; Oil=oil exports as \% of GDP; Agriculture=agricultural exports as \% in GDP; FDI=share of FDI in GDP. Variables $G D P_{1975}$, I rate, PC, Trade, Oil, and Agriculture are included in regressions as $\log$ (variable). P-values are in parentheses below coefficient estimates.

\begin{tabular}{|c|c|c|c|c|c|}
\hline Independent variable & $\begin{array}{c}\text { FDI } x \text { FIN } \\
\text { (1) }\end{array}$ & $\begin{array}{c}\text { FDI x Agriculture } \\
(2)\end{array}$ & $\begin{array}{l}\text { FDI x Oil } \\
\quad(3)\end{array}$ & $\begin{array}{c}\text { FDI x Schooling } \\
(4)\end{array}$ & $\begin{array}{c}\text { FDI x Trade } \\
(5)\end{array}$ \\
\hline$G \overline{G D P_{1975}}$ & $-1.152^{* * *}$ & $-1.217^{* * *}$ & $-1.203^{* * *}$ & $-1.189^{* * *}$ & $0.310^{* * *}$ \\
\hline & $(0.000)$ & $(0.000)$ & $(0.000)$ & $(0.000)$ & $(0.000)$ \\
\hline Schooling & $0.514^{* *}$ & $0.412^{*}$ & $0.483^{*}$ & 0.569 & $0.490^{*}$ \\
\hline & $(0.045)$ & $(0.100)$ & $(0.059)$ & $(0.147)$ & $(0.059)$ \\
\hline I rate & $1.331^{*}$ & $1.883^{* * *}$ & $1.465^{* *}$ & $1.534^{* *}$ & $1.503^{* *}$ \\
\hline & $(0.057)$ & $(0.009)$ & $(0.034)$ & $(0.025)$ & $(0.034)$ \\
\hline $\mathrm{PC}$ & 0.030 & 0.293 & 0.309 & 0.261 & 0.315 \\
\hline & $(0.942)$ & $(0.389)$ & $(0.372)$ & $(0.458)$ & $(0.379)$ \\
\hline Trade & -0.392 & -0.348 & -0.322 & -0.367 & -0.401 \\
\hline & $(0.250)$ & $(0.304)$ & $(0.354)$ & $(0.285)$ & $(0.272)$ \\
\hline Oil & -0.019 & -0.007 & -0.067 & -0.010 & -0.009 \\
\hline & $(0.816)$ & $(0.922)$ & $(0.581)$ & $(0.906)$ & $(0.908)$ \\
\hline Agriculture & -0.161 & 0.061 & -0.131 & -0.136 & -0.130 \\
\hline & $(0.193)$ & $(0.756)$ & $(0.280)$ & $(0.269)$ & $(0.282)$ \\
\hline FDI & $0.448^{* *}$ & $0.362^{* *}$ & 0.219 & 0.411 & $0.085^{*}$ \\
\hline & $(0.033)$ & $(0.017)$ & $(0.166)$ & $(0.376)$ & $(0.089)$ \\
\hline FDI $\mathrm{x}$ absorptive capacity & $0.260^{*}$ & -0.101 & 0.034 & -0.064 & 0.038 \\
\hline & $(0.097)$ & $(0.225)$ & $(0.529)$ & $(0.758)$ & $(0.753)$ \\
\hline Sub-Saharan dummy & -1.030 & -0.901 & -1.055 & -0.952 & -1.003 \\
\hline & $(0.125)$ & $(0.177)$ & $(0.125)$ & $(0.159)$ & $(0.143)$ \\
\hline Latin America dummy & $-0.967^{* *}$ & $-1.110^{* *}$ & $-1.073^{* *}$ & $-1.138^{* *}$ & $-1.042^{* *}$ \\
\hline & $(0.048)$ & $(0.020)$ & $(0.026)$ & $(0.025)$ & $(0.039)$ \\
\hline$R^{2}$-adjusted & 0.447 & 0.450 & 0.439 & 0.436 & 0.436 \\
\hline Observations & 69 & 69 & 69 & 69 & 69 \\
\hline
\end{tabular}

$a[]^{* * *}$ implies significant at $1 \%$ level; ${ }^{* *}$ implies significant at $5 \%$ level; ${ }^{*}$ implies significant at $10 \%$ level 
The coefficient for FDI is positive (0.571) and significant at the $5 \%$ level when FDI is interacted simultaneously with both the financial market indicator and human capital. While FDI x Fin enters positively in the regression and is statistically significant at 5\%, the coefficient for FDI x Schooling although insignificant, is negative. This surprising result suggest that well developed finacial market might make up for a low endowment of human capital, such that overall, FDI might have a positive and significant impact on growth. Thus, positive spillovers from FDI may coexist with a lower human capital endownment if the condition for well developed financial markets is met in the host country.

We then analyze simultaneously the conditions on natural resource abundance and development of financial markets that are required for generating positive effects of FDI on growth. The coefficient estimate for FDI is positive (0.491) and significant when FDI x Fin and FDI x Oil enter the regression. However, even though both interaction terms are insignificant, the coefficient for FDI x Oil is negative, suggesting that natural resources abundance might inhibit the benefits from FDI. Thus gains from FDI materialize in a country that is relatively scarce in natural resources but has well developed financial markets

A similar situation is found when FDI $x$ Fin is interacted with FDI x Agriculture. The coefficient for FDI is strongly significant at $1 \%$ level and positive (0.685). While the coefficient for FDI $\mathrm{x}$ Fin is significant and positive, the coefficient for FDI x Agriculture is also significant but negative (-0.150). Thus, countries with well developed financial markets and low shares of agricultural exports in GDP increase their welfare through FDI from FDI.

When FDI x Trade enters the regressions, the coefficients for FDI become negative with one exception: when FDI x Trade is combined with FDI x Fin, the coefficient for FDI is positive but insignificant. However, when FDI x Trade is regressed together with FDI x Oil, FDI is significant at $1 \%$ level and negative. This suggests that the growth of oil abundant countries that trade intensively might slow down when MNC's invest in their markets. 
Table 6: Robustness of absorptive capacities relative to each other: growth effects of simultaneous interactions between absorptive capacities and FDI The dependent variable is the average of per capita GDP growth rates from 1975 to 2000. Control variables: GDP $1975=$ initial GDP per capita; Schooling=educational attainment; I rate=investment rate, $\mathrm{PC}=$ private credit as \% in GDP; Trade=total trade as \% of GDP; Oil=oil exports as \% of GDP; Agriculture=agricultural exports as \% in GDP; FDI=share of FDI in GDP. P-values are in parentheses near coefficient estimates.

\begin{tabular}{|c|c|c|c|c|c|c|}
\hline ABSCAP & & FDIxFin & FDIxSchool & FDIxOil & FDIxAgric & FDIxTrade \\
\hline FDI*Fin & $\begin{array}{l}\text { FDI } \\
\text { FDIxFin }\end{array}$ & $\begin{array}{l}0.468^{* *}{ }_{(0.029)} \\
0.334^{* *}{ }_{(0.045)}\end{array}$ & & & & \\
\hline FDIxSchool & $\begin{array}{l}\text { FDI } \\
\text { FDIxFin } \\
\text { FDIxSchool }\end{array}$ & $\begin{array}{l}0.571^{* *}{ }_{(0.018)} \\
0.352^{* *}{ }_{(0.012)} \\
-0.043{ }_{(0.834)}\end{array}$ & $\begin{array}{l}0.110_{(0.796)} \\
0.055^{* * *}(0.009)\end{array}$ & & & \\
\hline FDI x Oil & $\begin{array}{l}\text { FDI } \\
\text { FDIxFin } \\
\text { FDIxSchool } \\
\text { FDIxOil }\end{array}$ & $\begin{array}{l}0.491_{(0.085)}^{*} \\
0.351_{(0.197)} \\
-0.007_{(0.901)}\end{array}$ & $\begin{array}{l}0.068_{(0.875)} \\
0.053_{(0.789)} \\
0.031_{(0.562)}\end{array}$ & $\begin{array}{l}0.179_{(0.227)} \\
0.031_{(0.557)}\end{array}$ & & \\
\hline FDIxAgric & $\begin{array}{l}\text { FDI } \\
\text { FDIxFin } \\
\text { FDIxSchool } \\
\text { FDIxOil } \\
\text { FDIxAgric }\end{array}$ & $\begin{array}{l}0.685^{* * *}{ }_{(0.006)} \\
0.463^{* *}{ }_{(0.059)} \\
-0.150^{*}{ }_{(0.089)}\end{array}$ & $\begin{array}{l}0.255_{(0.567)} \\
0.023_{(0.908)} \\
-0.097_{(0.265)}\end{array}$ & $\begin{array}{l}0.262_{(0.115)} \\
0.028_{(0.594)} \\
-0.096_{(0.263)}\end{array}$ & $\begin{array}{l}0.305^{* *}{ }_{(0.036)} \\
-0.098_{(0.249)}\end{array}$ & \\
\hline FDIxTrade & $\begin{array}{l}\text { FDI } \\
\text { FDIxFin } \\
\text { FDIxSchool } \\
\text { FDIxOil } \\
\text { FDIxAgric } \\
\text { FDIx Trade }\end{array}$ & $\begin{array}{l}0.713_{(0.443)} \\
0.395_{(0.226)}\end{array}$ & $\begin{array}{l}-0.210_{(0.734)} \\
0.010_{(0.959)} \\
0.086_{(0.469)}\end{array}$ & $\begin{array}{l}-0.173^{* * *}{ }_{(0.006)} \\
0.004^{* * *}{ }_{(0.008)} \\
0.082_{(0.609)}\end{array}$ & $\begin{array}{l}-0.228_{(0.667)} \\
-0.113^{* *}{ }_{(0.011)} \\
-0.115^{* * *}{ }_{(0.004)}\end{array}$ & $-0.196_{(0.722)}$ \\
\hline
\end{tabular}

$a[]^{* * *}$ implies significant at $1 \%$ level:** implies significant at $5 \%$ level; ${ }^{*}$ implies significant at $10 \%$ level 


\section{Conclusions}

This paper analyzes the necessary local conditions that enable FDI to generate welfare gains in host countries. The mix of these local conditions defines the absorptive capacity.

The relationship between FDI and economic growth is shaped by absorptive capacities that consist of development of financial markets, endowment of human capital, trade openness, agricultural intensity and natural resources abundance.

We first focus on the relationship between FDI and other growth determinants by constructing linear interaction terms between FDI and different measures for absorptive capacity. Using a cross section of 69 countries, we regress FDI and these individual interaction terms on the growth rate of GDP per capita after controlling for other growth determinants. We find that the contribution of FDI to economic growth is positive and significant Our results indicate that a minimum level of human capital and well developed financial markets are essential for positive spillovers from FDI to exist. The second exercise consists of a unified study of absorptive capacities that tests the robustness of the linear interaction terms previously constructed relative to each other. The results suggest that the most favorable economic environments for FDI are represented by countries with well developed financial markets that are either relatively scarce in natural resources or have low shares of agricultural exports in GDP. The condition of having well developed financial markets dominates in importance the condition for a threshold level of human capital.

\section{References}

Alfaro, L., Chanda, A., Kalemli-Ozcan, S., and Sayek, S. 2004. FDI and economic growth: the role of local financial markets Journal of International Economics, Elsevier, vol. 64(1), pages 89-112, October. 
Balasubramanyam,V.N., M. Salisu, M. and Sapsford,D. 1996.Foreign Direct Investment and Growth in EP and is Countries The Economic Journal, Vol. 106, No. 434, pp. 92-105

Bekaert, G., Harvey, C., and Lundblad, C. 2005. Does financial liberalization spur growth? Journal of Financial Economics, Elsevier, vol. 77(1), pages 3-55, July.

Blomstrom, M., Lipsey, R., and Zejan, M. 1994. What Explains Developing Country Growth? NBER Working Papers 4132

Borensztein, E., De Gregorio, J. and Lee, J-W. 1998. How does foreign direct investment affect economic growth? Journal of International Economics. Elsevier, vol. 45(1), pages 115-135, June.

Carkovic, M. and Levine,R. 2002 Does Foreign Direct Investment Accelerate Economic Growth?

Eaton, J. and Kortum, S. 2001. Trade in Capital Goods. NBER Working Papers. 8070, National Bureau of Economic Research, Inc.

Findlay, R.1978. Some Aspects of Technology Transfer and Direct Foreign Investment The American Economic Review vol.68, No.2, pages 275-279

Girma, S. 2005. Absorptive Capacity and Productivity Spillovers from FDI: A Threshold Regression Analysis Oxford Bulletin of Economics and Statistics vol.67, pages 261-306

Girma, S. and Görg,H. 2005. Foreign Direct Investment, Spillovers and Absorptive Capacity: Evidence from Quantile Regressions Kiel Working Papers 1248 Kiel Institute for the World Economy.

Gourinchas, P. and Jeanne, O. 2006. The Elusive Gains from International Financial Integration. Review of Economic Studies. 73, 715-741 
Greenwood, J., Hercowitz, Z., and Krusell, P. 1995. Long-Run Implications of InvestmentSpecific Technological Change. American Economic Review. Vol. 87 (3). p.342-62. June 1997

Kugler, M. 2006.Spillovers From Foreign Direct Investment: Within Or Between Industries? Borradores de Economia.003523, Banco de la Republica.

Levine, R., Loayza, N., and Beck, T 1999. Financial intermediation and growth : Causality and causes. Policy Research Working Paper Series. 2059, The World Bank.

Markusen, J. and Venables, A.J. 1999. Foreign direct investment as a catalyst for industrial development. European Economic Review. Elsevier vol. 43(2), pages 335-356, February.

Matsuyama,K. 2004. Financial Market Globalization, Symmetry-Breaking, and Endogenous Inequality of Nations Econometrica, Econometric Society, vol. 72(3), pages 853884,05 .

Papageorgiou, C., Lall, S. and Jaumotte, F. 2008. Rising Income Inequality: Technology, or Trade and Financial Globalization? IMF Working Papers 08/185, International Monetary Fund.

Prasad, E., Rogoff, K., Wei, S., and KoseM. 2007. Financial Globalization, Growth and Volatility in Developing Countries NBER Chapters, in: Globalization and Poverty, pages 457-516 National Bureau of Economic Research, Inc.

Rajan, R. and Zingales, L. 2001. The Great Reversals: The Politics of Financial Development in the 20th Century CRSP working papers 526, University of Chicago.

Xu, B. 2000. Multinational enterprises, technology diffusion, and host country productivity growth. Journal of Development Economics. Elsevier, vol. 62(2), pages 477-493. 